\title{
Effect of Return on Equity, Debt to Asset Ratio, Working Capital Turnover Dan Devidend Payout Ratio on Stock Return
}

\author{
Rona Tumiur Mauli Caroline* \\ Universitas Mercu Buana, Jakarta, Indonesia
}

DOI: $10.36348 /$ sjef.2020.v04i08.002

| Received: 14.07.2020 | Accepted: 27.07.2020 | Published: 09.08.2020

*Corresponding author: Rona Tumiur Mauli Caroline

Abstract

This research aims to analyse the influence of return on equity, debt to asset ratio, working capital turnover and dividend payout ratio to stock return and to know the factors of return on stock. The data source used is the secondary data obtained from the annual report of the food and beverage sub-sector manufacturing company listed on the Indonesia Stock Exchange (BEI) in 2014-2018. This research uses causal research design, the method used in this research is the purposive sampling method. The data analysis methods in this study used multiple linear regression analyses and their data processing using version 21 programs. Based on purposive sampling method, there are 65 final samples this research. The method of analysis used is statistical analysis in multiple linear regression test forms. Overall, the results of the study revealed that Return on Equity (X1) has no significant effect on the stock return, Debt to Asset Ratio (X2) has no significant effect on the stock return, Working Capital Turnover (X3) has a significant influence on the stock return, Devidend Payout Ratio (X4) has no significant effect on the stock return.

Keywords: Return on Equity, Debt to Asset Ratio, Working Capital Turnover, Devidend payout ratio, Stock return.

Copyright @ 2020: This is an open-access article distributed under the terms of the Creative Commons Attribution license which permits unrestricted use, distribution, and reproduction in any medium for non-commercial use (NonCommercial, or CC-BY-NC) provided the original author and source are credited.

\section{INTRODUCTION}

Economic development in Indonesia is supported by capital market developments. The capital market is the venue for a wide range of long-term financial instruments, such as debts, equities, derivative instruments, and other instruments. One of the most widely known capital market instruments is stocks. The company that has published its shares in the capital market is called the go public company. Seeing these open opportunities companies are trying to trade their stocks in the capital markets. By trading its shares in the capital market, the company can earn funds for its survival.

Capital markets play an important role in the economic activities of a country. In many countries, especially in countries that embrace the market economic system, the capital market has become one of the sources of economic advancement, because the capital market can be a source of alternative funds for the company. One of the advantages of capital market is its ability to provide capital in the long term and without limits. Thus, in order to finance investments in long-term projects and require large capital, it is proper for entrepreneurs to use the funds of the capital market.
Investment is essentially the placement of a number of funds at this time in the hopes of future profits.

Shares of go public company as investment commodity is a high risk. Because of its sensitivity to the changes that occur, either by the influence of the outside or in the state, changes in the field of politics, monetary economy, laws or regulations or changes that occur in the industry and the corporation that issued the stock itself. So that the investor in making a stock purchase requires thinking based on the data of the company concerned.

Investors are said to be good at investing if the investor can estimate how much return is expected from the investment. In addition, investors should be able to predict how far the possibility of saving the results (risk) should be accepted. Based on this, investing in investors requires a thorough consideration and analysis of the corporation. Therefore, investors need to have a number of information relating to stock return in order to assist in returning the decision about the company's shares that are eligible to be selected. 


\section{LITERATURE REVIEW}

Stock returns is a conservative type of investor, the ability of this type of risk responsibility is small that has investment objectives as a routine or additional income so that the minimum return in want is greater than the deposit. A much larger investment. By knowing the risk profit, the investor will know the right strategy to invest the stock.

According to Hartono [1], return is the result of the investment. Return can be either return (Realized Return) or return Expectasian (Expected Return), the realization return is a calculated return based on historical data. Return realization is very important because it can be used as one of the performance meters of the company. Return expectations are the expected return to be proleh by the investor in the future, so return expectations of its nature have not occurred.

Refunding decisions can be regarded as a form of capital budgeting. There is a preliminary cash advance followed by the savings of the future interest. This savings is demonstrated by the difference between the annual net cash flow that is required for old bonds with the net outflow required for new, refunded bonds. Calculating the initial cash flow out is more complicated. Therefore, the best way is to demonstrate an example of this method of evaluation.

Return on Equity is a special measure for the ownership of shareholders and business owners because it is a direct measure of the reward for the company's owners. The larger the ratio is generated hence it gives the increasingly strong position of the shareholders, because the ROE, the ratio of profit from shareholders.

Return on Equity is a ratio that measures the ability to generate profit by measuring the return on its own capital. If the ROE increases it will result in the price of the company's stocks rising, thereby increasing the profitability enjoyed by shareholders. Increased ROE a company will increase the Earning Per Share company. This means that ROE is the return of investment for shareholders ' accepted shareholders per share [2].

According to Brimingham, E.F. and Houston [3], Debt to Asset Ratio is a ratio of debt used to measure the comparison of total debt to total assets. In other words, how much the company's assets are financed by debt or how much the company's debt affects the management of its assets.

Researchers use debt to asset ratio (DAR) as leverage because DAR is able to provide information to investors that can be used as consideration in investing. Information about the use of debt by the company can benefit investors because with the use of the debt means the company has a good condition in obtaining profit [4].
Working Capital Turn Over (WCTO) within the company needs to be kept up to speed so that the company can obtain the expected profit in order to increase profitability. Fast slow working capital will affect the large of the funds that are tied to the working capital. Working Capital Turn Over, which quickly shows the working capital that is used more productive in generating certain levels of sales and profit so as to increase the profitability of the company.

Account receivable turn over) is also one of the major factors that determine the small profit that the company will gain. Some of the advantages gained by the company, if the management of receivables well, among other possibilities the company can pay all obligation on time and allow the company to operate more efficiently because there is no difficulty to obtain the necessary goods indirectly impact on the company's profit acquisition level [5].

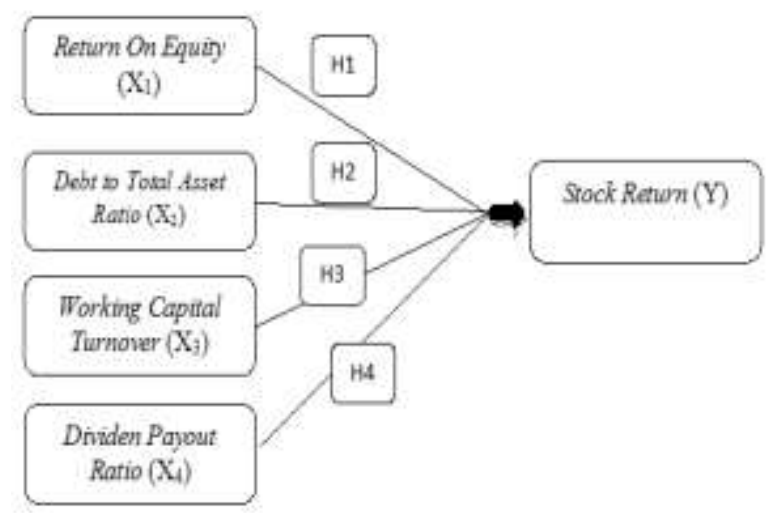

Picture-1: Mind Frame

Source: Hasil Olahan Penulis (2020)

\section{Effect of Return on Equity on Stock return}

Return On Equity (ROE) to provide return On the shares that are successfully obtained by the management as a result of capital use (capital) that has been provided by the owner after making payment to another financier, the higher the ratio means that the expected future emitment performance will be better, so the expected return of the stock will be high.

ROE has no positive effect on the high return of ROE shares causing the interest in public investment in the property companies ' stocks increased because of the profit to be received high. Likewise if the ROE is low, then the investment interest is down, and the price of the stock also falls.

Return on Equity is the benchmark of profitability, where shareholders generally want to know the level of profitability of the stock capital and the profit they have replanted in the form of an planted profit. ROE signifies the company not serving it on profit. Thus small-scale companies, not having ROE 
values that tend to increase rapidly in line with the increase in net income.

$\mathrm{H}_{1}=$ Return on Equity (ROE) significant effect on Stock return.

\section{Effect of Debt to Asset Ratio on Stock return}

Debt to Asset Ratio is a measure of how much a company's assets are in debt or how much the company's debt affects asset managers. The higher the value of DAR means the greater the source of funds through loans to finance assets. The high value of DAR shows high risk also because there is a company's constraints are not able to cover the Hutang-hutangnya with the assets that are owned so as to influence the return of the stock.

Thus, the higher level of debt means that the interest expense will be greater, which means it reduces profits and also indicates a high financial risk. This risk occurs because the company's financing through debt raises interest expense on debts. If the profit generated is insufficient to pay the debt and interest then the company will be in a default position that can lead to bankruptcy. As a result of this, the share price will change to a negative direction so that the level of stock return also negatively or decreases.

$\mathrm{H}_{2}=$ Debt to Asset Ratio (DAR) significant effect on Stock return.

\section{Effect of Working Capital Turnover on Stock return}

Working Capital Turnover is one of the ratios to measure or assess the effectiveness of the company's working capital over a period or during a period. Working capital In this case is an asset where the funds that are embedded in it will be able to be free again in a short time. Thus working capital is the whole of the amount of current assets.

If, the company sets low current debt, then the ratio measures the business activity on the excess of current assets. So the employee will have an increase in stocks and do not undergo bankruptcy.

$\mathrm{H}_{3}=$ Working Capital Turnover (WCTO) significant effect on Stock return.

\section{Effect of Dividend Payout Ratio influence on Stock return}

Dividends are the result of business activities conducted by the management aimed at seeking profit through the effectiveness of activities undertaken and financing efficiency efforts [6]. The dividend payout ratio determines the amount of profit divided in the form of cash dividends and net profit earned as dividends, meaning no profit withheld and ultimately minimised the internal funding source that can be used to grow the business.

$\mathrm{H}_{4}=$ Dividend Payout Ratio (DPR) significant effect on Stock return.

\section{RESEARCH METHODS}

This research is a quantitative study. Data collected is secondary data that has been processed by the company and has been published in the form of financial statements or in other words the data is not contained in the company concerned. This data is obtained from the summary of financial statement which is listed in Indonesia Capital Market Directory (ICMD) and various data sources website www.idx.co.id.

The population in this research is a manufacturing company in the field of food and beverage listed on the Indonesia Stock Exchange in the period 2014-2018. Sampling is done with the method Purposie Sampling with the following criteria: (1) It is a manufacturing company Sub sector Food and Beverages listed on the Indonesia Stock Exchange (IDX) during the period 2014-2018. (2) The company's manufacturing Sub-sector Food and Beverages data is not found consecutively during the period 2014-2018 (IPO). (3) Companies that suffer losses during the period 2014-2018.

In this study consists of four variables $(\mathrm{X})$ and one bound variable (Y). Return on Equity (X1), Debt to Asset Ratio (X2), Working Capital Turnover (X3), Dividend Payout Ratio (X4) and Stock return (Y). In order to find the effect of Return on Equity (ROE), Debt to Asset Ratio (DAR), and Working Capital Turnover (WCTO), Dividend Payout Ratio (DPR) against Stock return, the study used several statistical test tools, namely double linear regression, T-Test, and F-Test.

\section{RESULTS AND DISCUSSION \\ Multiple Linear Regression Analysis}

Using multiple linear analysis can be known the influence of free variables against bound variables. The following is a summary of multiple linear analyses: 
Table-1: Multiple Linear Regression

\begin{tabular}{|c|c|c|c|c|c|c|}
\hline \multicolumn{7}{|c|}{ Coefficients $^{\mathrm{a}}$} \\
\hline \multirow[t]{2}{*}{ Mod } & & \multicolumn{2}{|c|}{ Unstandardized Coefficients } & \multirow{2}{*}{$\begin{array}{l}\text { Standardized } \\
\text { Coefficients } \\
\text { Beta }\end{array}$} & \multirow[t]{2}{*}{$\mathrm{T}$} & \multirow[t]{2}{*}{ Sig. } \\
\hline & & $\mathrm{B}$ & Std. Error & & & \\
\hline \multirow{5}{*}{1} & (Constant) &, 005 & ,102 & &, 052 &, 959 \\
\hline & ROE &, 010 &, 001 &,- 039 & -279 & ,781 \\
\hline & DAR &, 068 &, 002 &, 027 & , 182 &, 856 \\
\hline & WCTO & 8,380 &, 024 &, 048 & 2,330 &, 043 \\
\hline & DPR & 4,280 &, 009 &, 129 & ,926 &, 359 \\
\hline
\end{tabular}

a. Dependent Variable: $Y$

Based on Table-1 above, then the equation of a regression return in stock company manufacturing in the field of food and beverages is as follows:

\section{$\mathrm{Y}=0,005 \mathrm{C}+0,010 \mathrm{ROE}+\mathbf{0 , 0 6 8} \mathrm{DAR}+\mathbf{8 , 3 8 7}$}

\section{WCTO + 4,287 DPR + e}

The outcome of the multiple linear regression equation gives understanding:

1. The constant value worth 0.005 means that if the Retun on equity, debt to asset ratio and working capital turnover and debt payout ratio is 0 , then the negative value of the shares is 0.005

2. The value of Return on equity (ROE) of 0.010 means that if another variable is fixed and return on equity increases by $1 \%$ then the stock return will increase by 0.010 .

3. The coefficient of debt to Asset ratio (DAR) is 0.068 meaning that if another variable is fixed and debt to asset ratio increases by $1 \%$, the return of stock will increase by 0.068 .

4. Value of Working capital turnover (WCTO) of 8.380 means that if another variable is fixed and the working capital turnover will increase by $1 \%$, then the stock return would have increased by 8.380 .

5. The value of dividiend payout coefficient (DPR) of 4.280 means that if another variable is fixed value and the Dividiend payout ratio is increased by $1 \%$ then the stock return will be increased by 4.280 .

\section{Hypothesis Test (T-Test)}

To analyze the influence of the Return on Equity (X1) variable, Debt to Asset Ratio (X2), Working Capital Turnover (X3) partially against the Return share $(\mathrm{Y})$ variable, it will be summarized in the following table:

Table-2: Summary of calculation resultsHypothesis Test

\begin{tabular}{c|c|c|} 
Code & Hyjpothesis & Conclusion \\
\hline H1 & Retum on Equity no effect on Stock Retm & Rejected \\
\hline H2 & Dett to Asset Ratio no effect to Stock Return & Rejected \\
\hline H3 & Working Captal Tum Over effect to Stock Return & Accepted \\
\hline H4 & Deridend Payout Ratio no effect to Stock Retum & Rejected \\
\hline
\end{tabular}

From Table-2 can be known that $\mathrm{T}$ count for variable Return on Equity (X1) of 0.279 with a significant rate of 0.781 greater than 0.005 which means Return on Equity has no significant effect on stock return. In conclusion $\mathrm{HO}$ accepted $\mathrm{H} 1$ rejected, this indicates that ROE has no effect on stock return.

For the variable Debt to Asset Ratio (X2), it is known that the count of 0,182 with a significant rate of 0.856 which means Debt to Asset Ratio has no significant effect on the stock return. In conclusion HO accepted $\mathrm{H} 1$ rejected, this indicates that DAR does not affect the stock return.
From Table-2, it can be known that $\mathrm{T}$ count for the variable Working Capital Turnover (X3), known to calculate at 2.330 with a significant rate of 0.043 which means that the Working Capital Turnover significantly affect the stock return. In conclusion $\mathrm{HO}$ rejected $\mathrm{H} 1$ accepted, it shows that WCTO affects stock return.

From Table-2, it can be known that $\mathrm{T}$ count for the dividend payout ratio (X4), known to calculate at 0,926 with a significant rate of 0.359 which means that the Dividend Payout Ratio significantly affect the stock return. In conclusion $\mathrm{HO}$ accepted $\mathrm{H} 1$ rejected, it shows that DPR affects stock return. 


\section{Determination Coefficient Test Results (R2 Test)}

$\mathrm{R} 2$ test is used to measure how far the ability of the model in the variation of the dependent variable. $\mathrm{R} 2$ values range from 0 to 1 . If $\mathrm{R} 2=1$ shows that $100 \%$ of the independent variables are able to explain the dependent variable. $\mathrm{R} 2=0$ means that there are no variants explained by the independent variables [7]. Following are the results of the coefficient of determination (R2) test:

\begin{tabular}{|l|l|l|l|l|}
\hline \multicolumn{4}{|c|}{ Model Summary } \\
\hline Model & R & R Square & Adjusted R Square & Std. Error of the Estimate \\
\hline 1 & $.280^{\mathrm{a}}$ & .078 & .017 & .60959 \\
\hline \multicolumn{4}{|c|}{ a. Predictors: (Constant), DPR(X4), DAR(X2), ROE(X1), WCTO(X3) } \\
\hline
\end{tabular}

Hypothesis Test (F-test)

\begin{tabular}{|rl|r|r|r|r|r|}
\hline \multicolumn{7}{|c|}{ ANOVA $^{\mathrm{a}}$} \\
\hline \multicolumn{1}{|c|}{} & Sum of Squares & $\mathrm{df}$ & Me an Square & \multicolumn{1}{c|}{$\mathrm{F}$} & Sig. \\
\hline & Regression &, 064 & 4 &, 016 & 3,303 &, $050^{\mathrm{b}}$ \\
& Residual & 2,808 & 53 &, 053 & & \\
& Total & 2,872 & 57 & & & \\
\hline
\end{tabular}

a. Dependent Variable: $Y$

b. Predictors: (Constant), X4, X3, X1, X2

Based on Table-2 digits R Square is 0.078 as the basis of calculating coefficient of determination. The value of coefficient of determination is $7.8 \%$ which means variable ROE, DAR, WCTO, DPR have a simultaneous effect on return on shares while the remaining $92,2 \%$ is influenced by other variables not addressed in this study.

The coefficient value of $F$ is 3.303 and a significant value of 0.050 which can be interpreted that $\mathrm{F}$ is greater than 0.05 it can be interpreted as Ho accepted so that the ROE, DAR, WCTO, DPR variables collectively affect the return of the stock.

\section{DISCUSSION}

\section{The effect of Return on Equity (ROE) on stock return}

In this study showed that ROE in T-Test, Ho received and $\mathrm{H} 1$ was rejected, which means that ROE has no partial effect on return on shares. Unknown $t$ count for variable Return on Equity (X1) of- 0.055 with a significant rate of 0.956 . Greater than 0.005 which means Return on Equity has no significant effect on stock return.

Return On Equity is a ratio that measures the ability to generate profit by measuring the return on its own capital. If the ROE increases it will result in the price of the company's stocks rising, thereby increasing the profitability enjoyed by shareholders. The results of this research are in line with research by Budiharjo [8] which states that ROE and ROA have no effect on stock returns and DER has a positive effect on stock returns.
Effect of Debt to Asset Ratio (DAR) on stock return For the variable DEBT to Asset Ratio (X2) in Test T, Ho is accepted and H1 is rejected which means that DAR has no partial effect on stock return.. It is known $\mathrm{T}$ calculate of -1.286 with a significant rate of 0.204. Greater than 0.005 which means Debt to Asset Ratio has no significant effect on return on shares.

Researchers use debt to asset ratio (DAR) as leverage because DAR is able to provide information to investors that can be used as consideration in investing. Information about the use of debt by the company can benefit investors because with the use of the debt means the company has a good condition in obtaining profit [4].

\section{Effect of Working Capital Turnover (X3) on stock return}

In this study showed that WCTO in T test, Ho accepted and $\mathrm{H} 1$ accepted means that WCTO affects partially to stock return. Unknown t count for Working Capital Turnover (X3) variable of 3.017 with a significant rate of 0.004 . Smaller than 0.005 which means that the Working Capital Turnover significantly affects the stock retun.

The Working Capital Turnover in the company needs to be kept up to speed so that the company can obtain the expected profit in order to increase profitability. Fast slow working capital will affect the large of the funds that are tied to the working capital. Working Capital Turn Over, which quickly shows the working capital that is used more productive in generating certain levels of sales and profit so as to increase the profitability of the company. 


\section{CONCLUSIONS AND SUGGESTIONS}

Based on the results of the analysis and the discussion that has been stated above, it can be concluded as follows:

1. The result of the $\mathrm{F}$ test shows that the coefficient of $F$ is 3.597 and a significant value of 0.019 which can be interpreted that $F$ is greater than 0.05 then it can be interpreted as Ho accepted. This shows that Return on Equity, Debt to Asset Ratio and Working Capital urnover jointly affect the Return share variable.

2. The result of the T-Test indicates the effect of an independent variable against the dependent variable partially is: Return on Equity has no partial effect on Stock return, DEBT to Asset Ratio does not partially affect the Return of stock, Working Capital Turnover and Dividend Payout Ratio partially affects the Return of stocks.

This research in the future is expected to present the results of more qualified research with some inputs on several things that can be a reference to the renewal of research including:

1. Further research is expected to use a wider sample, thus, the samples become more representative of the population, as well as the results of research gained will be more beneficial because it shows the tendency of existing populations.

2. For investors and prospective investors who will invest stocks should focus on investing want to benefit from the form of Stock return, so it will be easier in determining will plant stocks in which companies.

\section{REFERENCES}

1. Hartono, J. (2014). Metode Penelitian Bisnis (Dosen Faku). Yogyakarta: BPFE Yogyakarta.

2. Aryaningsih, Y. N., Fathoni, A., \& Harini, C. (2018). Pengaruh Return on Asset (ROA), Return on Equity (ROE) dan Earning per Share (EPS) terhadap Return Saham pada Perusahaan Consumer Good (Food and Beverages) yang Terdaftar di Bursa Efek Indonesia (BEI) Periode 2013-2016. Journal of Management. 4(4). https://doi.org/2502-7689

3. Brimingham, E. F., \& dan Houston, J. F. (2014). Dasar-dasar Manajemen Keuangan. Jakarta: Salemba Empat.

4. Safitri, O., Sinarwati, \& Atmadja, A. T. (2015). Analisis Pengaruh Rasio Likuiditas, Leverage dan Profitabilitas Terhadap Return Saham Pada Perusahaan Manufaktur Yang Terdaftar di Bei. 3(1):1-12.

5. Andrea, R. D. (2019). Analisis Pengaruh Working Capital Turn Over ( Wcto ) Dan Receivable Turn Over ( Rto) Terhadap Return On Assets ( Roa) Pada Pt . Xyz. 13(2).

6. Gendro, W., \& dan Hadri, K. (2017). Manajemen Keuangan Lanjutan: Berbasis Corporate Value Creation, UPP STIM YKPN, Yogyakarta.

7. Ghozali, I., \& Ratmono, D. (2017). Analisis Multivariate dan Ekonometrika dengan Eviews 10. Badan Penerbit Universitas Diponogoro: Semarang.

8. Budiharjo, R. (2018). Pengaruh Profitabilitas Dan Leverage Keuangan Terhadap Return Saham Pada Perusahaan Industri Konsumsi Makanan Dan Minuman Yang Terdaftar Di Bursa Efek Indonesia 2014-2016. 